Standards Institution. Some of the Electricity Commissioners' regulations are reviewed with particular reference to their latest modifications for light lines. Details are given of the design evolved by the British Electrical and Allied Industries Research Association for light high-voltage lines up to $22 \mathrm{kV}$. which is now being considered by the B.S.I. With slight modifications, this design can be adaptable for $33-\mathrm{kV}$. working and also for heavier conductors. An alternative design, employing wood ' $\mathrm{H}$ ' poles and suspension insulators, is suggested for special cases. A low-voltage design is also detailed and recommended.

The design covered by the draft B.S. specification is suggested for general adoption in Great Britain for high-voltage lines up to $22 \mathrm{kV}$. with conductors of 0.04 sq. in. or less. With minor modifications this design could also be used for the larger sizes of conductors and for $33-\mathrm{kV}$. working. To meet special local conditions, an ' $\mathrm{H}$ ' pole suspension type of line could be provided. Standard designs for insulators, clamps, joints, stay rods, etc., should be prepared and be obtainable from any of the usual suppliers. A joint meeting between the supply undertakers and the railway companies should be arranged to consider whether modifications to the present standard conditions for railway crossings are not justifiable in the light of up-to-date experience. A discussion between supply undertakers and Post Office authorities is desirable, to determine whether the present somewhat onerous conditions required by the latter could not be modified considerably, and greater use made of 'joint user' poles.

\section{Trade Unionism and Scientific Workers}

UNDER the title "British Trade Unionism", the Association of Scientific Workers has issued a short study course for scientific workers prepared by Dr. J. Kuczynski and a study group of the Central London Branch, which was formed early in 1942, on trade union history with special reference to the development of non-manual organization and the history of the Association of Scientific Workers in particular. The booklet is in five chapters: why trade unions were formed in Great Britain and how they were developed; how scientific workers came to found a trade union; a short history of the Trades Union Congress; the structure of the Trades Union Congress ; and the story of the Association of Scientific Workers. Of these the second and last show a certain lack of proportion and perspective. Within the limits imposed by pamphlet size, however, the first and the last three chapters give a concise--but biased, not to say prejudiced-account of the development of trade unionism in Great Britain and the association of professional defence organizations of scientific workers with this movement. Limitations of size, however, cannot excuse the paucity of the bibliography and the absence of bibliographic detail. The writers would do well to remember that history and propaganda are ill consorts.

\section{Department of Scientific and Industrial Research : Appointments}

THE Lord President of the Council has appointed Dr. A. Parker to be director of fuel research in the Department of Scientific and Industrial Research. Dr. Parker joined the staff of the Department of Seientific and Industrial Research in 1928 as assistant director of water pollution research. He had pre- viously been engaged for some ten years on research for the gas industry, including full-scale experimental work, as senior research chemist to the Joint Committee of the University of Leeds and the Institution of Gas Engineers. Since the outbreak of War he has been acting-director of water pollution research. $\mathrm{He}$ has served for many years on the Council of the Institution of Chemical Engineers and has been a vice-president of the Institution.

Mr. E. Barnard has been appointed principal assistant secretary in the Department of Scientific and Industrial Research. Mr. Barnard joined the administrative staff of the Department in 1919, and has been director of food investigation since 1934.

Mr. R. O'F. Oakley and Mr. G. R. D. Hogg have been appointed assistant secretaries in the Department. Mr. Oakley joined the administrative staff of the Department in 1920, after previous Government service in the Patent Office. $\mathrm{He}$ became assistant to the director of fuel research in 1938, but since 1940 his services have been lent to the Ministry of Home Security as deputy chief adviser, Research and Experiments Department. Mr. Hogg joined the administrative staff of the Department in 1920, and was appointed establishment officer in the Department on the outbreak of the War.

\section{Announcements}

Sir Henry Dale, president of the Royal Society and director of the Royal Institution, has been awarded the Harben Gold Medal by the Royal Institute of Public Health and Hygiene.

Mr. P. I. DeE, University lecturer in physics in the University of Cambridge, has been appointed to the chair of natural philosophy in the University of Glasgow as from October 1 next. The chair becomes vacant by the retirement under the age limit of Prof. E. Taylor Jones.

The Pilgrim Trust has purchased the residue of Newton's library which was being offered for sale (see Nature, April 10, p. 416). Scientific workers and other students will welcome the news that this unique historical material will be preserved in Great Britain.

The following have been elected officers of the Royal Astronomical Society for the ensuing year: President, Prof. E. A. Milne, Rouse Ball professor of mathematics, University of Oxford ; Treasurer : Mr. J. H. Reynolds; Secretaries : Dr. H. R. Hulme, chief assistant, Royal Observatory, Greenwich ; and Mr. D. H. Sadler, superintendent of the "Nautical Almanac"; Foreign Secretary: Sir Arthur Eddington, Plumian professor of astronomy, Cambridge; Council: Miss M. G. Adam, chief assistant (astronomy), University Observatory, Oxford; Dr. E. C. Bullard, Smithson research fellow of the Royal Society; Prof. J. A. Carroll, professor of natural philosophy, University of Aberdeen; Dr. T. G. Cowling, lecturer in mathematics, University of Manchester ; 'Mr. F. J. Hargreaves; Dr. A. Hunter; Captain W. N. McClean; Dr. G. C. McVittie, reader in mathematics, University of London (King's College) ; Prof. L. M. Milne-Thomson, professor of mathematics, Royal Naval College, Greenwich; Mr. H. W. Newton; Mr. F. J. Sellers; and Mr. W. M. Witchell. 